\section{$\mathrm{Y}-12$}

OAK RIDGE

$\mathrm{Y}-12$

PLANT
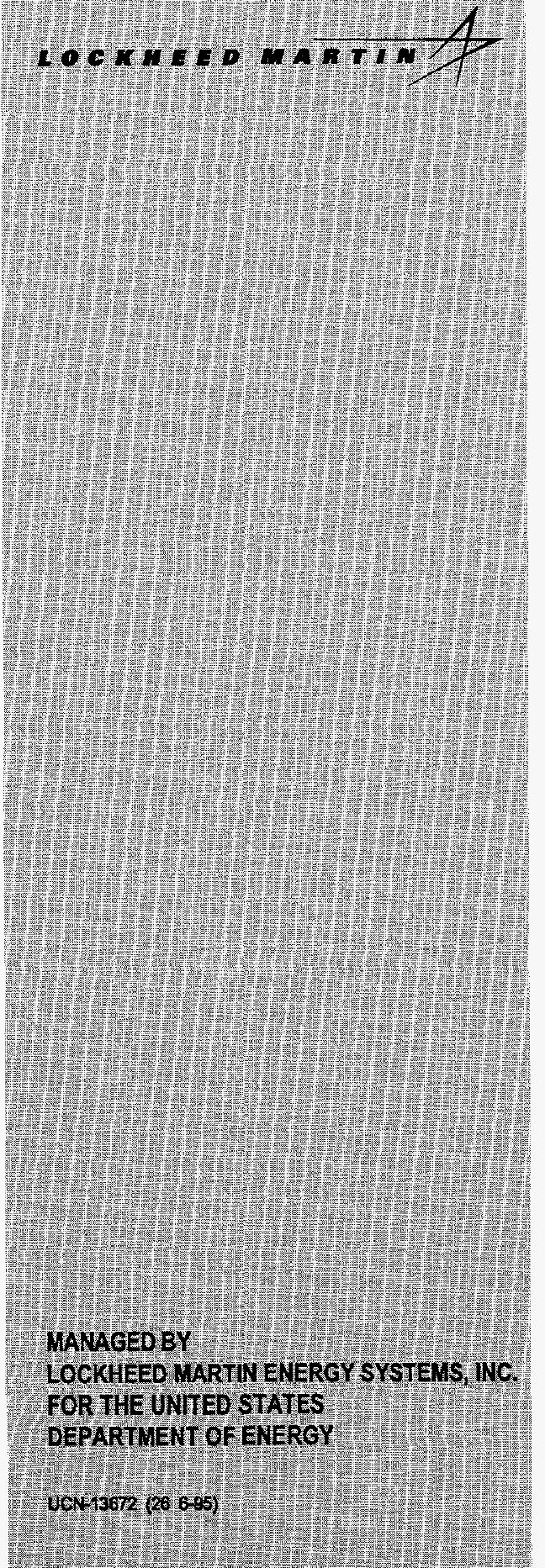

RECEIVED

AU6 11 1997

YIAMT-417
Project Accomplishment Summary

for

Project Number 94-MULT-912-ES-04

\title{
EXHAUST GAS SENSORS
}

\section{MASTER}

John Hiller
Lockheed Martin Energy Systems, Inc.

T. J. Miree

Ford Motor Company

February 9, 1997

Approved for Public Release; distribution is unlimited.

\author{
Prepared by the \\ Oak Ridge Y-12 Plant \\ managed by
}

LOCKHEED MARTIN ENERGY SYSTEMS, INC. for the

U.S. DEPARTMENT OF ENERGY under contract DE-AC05-84OR21400 


\section{DISCLAIMER}

This report was prepared as an account of work sponsored by an agency of the United States Governıent. Neither the United States Government nor any agency thereof, nor any of their employees, makes any warranty, express or implied, or assumes any legal liability or responsibility for the accuracy, completeness, or usefulness of any information, apparatus, product, or process disclosed, or represents that its use would not infringe privately owned rights. Reference herein to any specific commercial product, process, or service by trade name, trademark, manufacturer, or otherwise, does not necessarily constitute or imply its endorsement, recommendation, or favoring by the United States Government or any agency thereof. The views and opinions of authors expressed herein do not necessarily state or reflect those of the United States Government or any agency thereof. 


\section{DISCLAIMER}

This report was prepared as an account of work sponsored by an agency of the United States Government. Neither the United States Government nor any agency thereof, nor any of their employees, makes any warranty, express or implied, or assumes any legal liability or responsibility for the accuracy, completeness, or usefulness of any information, apparatus, product, or process disclosed, or represents that its use would not infringe privately owned rights. Reference herein to any specific commercial product, process, or service by trade name, trademark, manufacturer, or otherwise does not necessarily constitute or imply its endorsement, recommendation, or favoring by the United States Government or any agency thereof. The views and opinions of authors expressed herein do not necessarily state or reflect those of the United States Government or any agency thereof. 


\section{DISCLAMIER}

Portions of this docament may be illegible in electronic iroge products. Irogges are produced from the best available original docoment. 


\section{PROJECT ACCOMPLISHMENT SUMMARY}

Project Title: $\quad$ Exhaust Gas Sensors

DOE TTI Number: 94-MULT-912-ES-04

CRADA Number: 94MULT-912ES

Partner(s): $\quad$ USCAR Low Emissions Partnership

\section{BACKGROUND}

The automotive industry needed a fast, reliable, under-the-hood method of determining nitrogen oxides in automobile exhaust. This technology did not exist. The Y-12 plant was selected for this aspect of the program because of its work with emissions monitoring and instrumentation development.

\section{DESCRIPTION}

The objective was, in the end, to build an apparatus that could measure nitrogen oxides in automobile exhaust, much like the oxygen sensors currently in use. Several technologies were pursued concurrently. These sensing technologies were based on light absorption, electrochemical methods, and surface mass loading. The Y-12 plant was selected to study the methods based on light absorption.

The program, in time, broke down into three main parts. The first phase was defining the detailed technical objectives of the sensors - this was the role of the automobile companies. The second phase was to develop prototype sensors in the laboratories-the national laboratories. The final phase was testing of the prototype sensors by the automobile industries.

\section{BENEFITS TO DOE}

The principal benefit to the DOE is improved sensing of emissions, such as would be expected from a facility that is reprocessing uranium or plutonium.

\section{ECONOMIC IMPACT}

There is no economic impact from this work. This program was canceled a few months into what was to be a three-year effort.

\section{PROJECT STATUS}

This project is terminated. 
DOE FACILITY POINT(S) OF CONTACT FOR PROJECT INFORMATION Dr. John Hiller

Lockheed Martin Energy Systems, Inc.

PO Box 2009

Building 9203, Mail Stop 8084

Oak Ridge, Tennessee 37831-8084

Voice: 423 574-0287

Facsimile: 423 576-2782

\section{COMPANY SIZE AND POINT(S) OF CONTACT:}

T. J. Miree, Program Manager

US CAR Low Emissions Partnership

Ford Motor Company

Engine Support Systems Technologies

17100 Southfield Road

Allen Park, MI 48101

Information on the size, sales, employment number, etc. of the automotive industry would best be directed to Mr. Miree.

PROJECT EXAMPLES

This project was canceled before any tangible results were planned or accomplished.

TECHNOLOGY COMMERCIALIZATION

This project was canceled before any commercialization was planned or accomplished. 
DISTRIBUTION

John Hiller, MS-8084, 9203

Ray Ford, MS-8084, 9203

Andy Stevens, DOE OR, MS-8009, 9704-2

Diane Bird, DOE DP-17

Bill Wilburn, MS-8015, 9704-2

Y-12 Central Files, MS-8169, 9711-5 (3 copies)

T. J. Miree, Program Manager, US CAR Low Emissions Partnership, Ford Motor Company, Engine Support Systems Technologies, 17100 Southfield Road, Allen Park, MI 48101 (5 copies) 